\title{
Patronage-Clientelism and Political Identity of Chinese Candidate A Case Study of PSMTI in Medan, North Sumatera in General Election 2014
}

\author{
Ahmad Taufan Damanik \\ Department of Politics \\ University of North Sumatera
}

\begin{abstract}
This essay seeks to discuss how patronage and clientelism being performed, developed and emphasized by political identity, which is how the ethnic or religious identity, as well as network and religious entities, used to distribute patronage and clientelism. Some previous research proved that money politic and efforts to enhance votes are more effective when primordialism issue plays its role. Sentiments, symbols and ethnic entities, as well as religion, significantly have strong influence in shaping the behaviors of voters, although it does not stand alone. Money politic has reciprocal relation with political identity. The issues that we are going to discuss is the electoral practice of candidates of Chinese groups in North Sumatra for three levels of parliament in the first zone of the election. The solidity ofChinese ethnic group is also fragile where the social politic domain related to clan and interest also embellishes social relationships among them. However, there is cultural mechanism presents along with the senior leaders whose capacity to consolidate various groups of social politic and interest. The selected candidates are introduced to the Chinese community leaders to get support from both aspects which are votes and finance. The success team also managed to lobby the political party to place their candidates in voting zones which supporting each other at district, provincial and national level. Social projects are organized intensively as part of softer and elegance patronage, rather than buying the voters
\end{abstract}

Keywords-Patronage-Clientelism, election,Political Identity.

\section{INTRODUCTION}

Chinese ethnic group is a minority in North Sumatera (3,63 percent of 13,5 million population), while for Medan city alone has $10,7 \%$. However, economically the Chinese has the most dominant power not only in the urban area in the sectors of commerce and industry but also in the rural areas in the sectors of plantation, agriculture, farming and fishery/marine. The history of the economic power of Chinese in North Sumatra province, particularly in Medan started before the independence of Indonesia.

According to Leo Suryadinata, actually, since the beginning of Indonesia nationalism formation, the marginalization of Chinese has occurred by excluding them in the process of formulating the nation and defining Indonesian as the indigenous people only. The administration of Sukarno tried to recognize the Chinese offspring - those who were born in Indonesia and speak Bahasa Indonesia, while for those who were born in China and still speak their mother language cannot be recognized as Indonesian. At the same time, the assimilation and integration effort had been emphasized by the New Order. It is more open after the reformation indicated by the blooming Chinese social politic organizations, Chinese culture is allowed to be performed including the recognition of Konghucu religion in the era of Gus Dur.

The rise of PSMTI (Indonesian Tionghoa Social Clan Association) organization is part of Chinese awareness to be more active in various aspects of social politic, cultural apart from the economic. This social-politic breakthrough cannot be separated from the revitalization of the political identity of the Chinese in the era of democracy. At the same time, their political course cannot be separated from the issue of money politics or patronage and clientelism which growing stronger in the electoral practice of general election in Indonesia. A study conducted in the legislative election in 2014 is trying to explore two aspects above - how the Chinese political identity formed and fortified and how the patronage and clientelism practiced and developed to win the general election

\section{THEORETICAL REVIEW}

\section{Ethnic Identity-Political Identity}

The ethnic identity is an adaptive phenomenon, and in responding to changing situation, the collectivity boundaries could be expanded, and even person or some people can leave and join in more than one community. Ethnicity does not emerge in given but is defined and redefined, constructed and reconstructed by the elite for the politic and economic interest. In another word, ethnicity is a mechanism of social organization to compete for politic and economic resource competition

\section{Patronage-Clientelism}

Patronage, according to Martin Sefter is "a divisible benefit that politicians distribute to individual voters, campaign workers or contributors in exchange for political support. Patronage thus includes cash, goods, services and other economics benefits (such as jobs or contracts) that politicians distribute to supporters or potential supporters. Two critical terms are patronage and clientelism which, as understood here, refer respectively to) the goods or other favours that are exchanged in political relationships, and ii) the nature of the relationships themselves.1 Following Hutchcroft (2013), I define patronage as a "material resource derived from public 
sources and disbursed for particularistic benefit"; clientelism refers to a "personalistic relationship of power" [emphasis in original].

Combining these two theories - the ethnic politics in one side and the patronage and clientelism in the other side, the researcher intents to learn how patronage and clientelism being practiced, developed and fortified by ethnic identity or religious and how ethnicity social network and religion used to distribute the patronage and clientelism.

\section{RESEARCH METHOD}

This research uses the qualitative method, in several occasions uses shadowing approach, by following selected respondents to learn how they design the plan to win, manage the thinktank team, decided the distribution form and pattern of patronage as well as strategy to mobilize the clientelism, campaign model, etc. The researcher also conducted an indepth interview with candidates, think-tank team, Chinese leaders as well as some community members to deepen the observation results

\section{DISCUSSION}

Political identity is also used by Chinese candidates to fortify patronage, as the non-Chinese candidates do. The difference lies in the method and pattern of approach related to the uniquity of respective culture and political position. With the minority position, the Chinese candidates conduct it more exclusively and require more voters rather than rely on Chinese voters only. Candidate from PSMTI who run through PDIP is proven as the most succeed managing the political identity and patronage-clientelism. The main figure is Sofyan Tan who runs for DPR RI from the North Sumatera 1 electoral zone (covering Medan 1 and 2, Deli Serdang, Serdang Bedagai and Tebing Tinggi). Then, Brilian Moktar who run for DPRD North Sumatra, and Hasyim SE and Wong Chun Sen for DPRD Medan. These four run together and shared their electoral zone properly.

Each of them has their think-tank team but share a collective team to manage their campaign. Sofyan Tan sets the core team with his NGO activist colleagues who have been struggling with him in educational issue. In addition, through some social activities, he also makes use of political party cadres who are close to the grass root.

While, Brilian Moktar is more flexible, not too structured, usually from the Tionghoa youth activist and young leaders. The team of Hasyim and Wong Chun Sen are quite similar, and in many activities worked together with the team of Brilian Moktar. Apart from all of these, there was a special team from PSMTI, led by Chinese leaders - Edi and Halim Lo. These members of the PSMTI also worked for Sofyan, Hasyim, and Wong Chun Sen.

Meanwhile, Iskandar ST the founder and the chair of PASTI (Paguyuban Social Tionghoa Indonesia) as well as the general secretary of National Democrat of North Sumatra has failed to get sufficient votes since PASTI does not have sufficient supports from the Chinese community. Similar goes to other names from PASTI who did not succeed. From the INTI group, only Sonny Firdaus (Gerindra) who won a seat in North Sumatra DPRD. Other candidates from INTI, including the incumbent - Lily MBA the spouse of Sony Firdaus was also failed. There are other candidates from Democrat, PKPI did not succeed utilizing the cultural network of INTI.

Compared to candidates from other Chinese communities, the four candidates of PSMTI who run through PDIP managed to have substantial number of votes. Sofyan Tan, for example, won in Medan Kota (7140 votes), in Medan Area (7552 votes), Medan Sunggal (5351 votes), Medan Tuntungan (5688 votes), Medan Perjuangan (4820 votes) and areas with many Chinese populations such as Medan Timur and Medan Petisah, but Sofyan also gained significant votes in non-Chinese electoral areas. As the numerous votes achieved by Brilian Moktar in North Sumatra 1 electoral area - all over Medan, with a maximal vote in the area which more or less similar to ones where Sofyan had big votes. Meanwhile, their joint for DPRD Medan, in Medan 1 electoral area Hasyim had significant votes in Medan Kota (4178) and Medan Area (6417), and in Medan 4 electoral area, Wong Chun Sen had significant votes in Medan Perjuangan (2228) and Medan Timur (3398). This main victory electoral area has significant Chinese population.

\section{Internal Consolidation of Chinese Community}

Long before the election, there has been various consolidation processes in the internal community of Chinese. The most popular social politic figure - Sofyan Tan has conducted consolidation using the PSMTI organization and the leadership of Tan Sri of Tan clan in approaching leaders of other clans. Sofyan also uses his leadership in education field through the famous Iskandar Muda Educational Foundation that he owned.He has also attachment with various community leaders since he is also a senior NGO activist. As a nationalist, Sofyan is aware of the internal support of Chinese although he is supported by other ethnic groups, mainly from the Muslim majority. The approach is conducted with his partners - Brilian Moktar, Hasyim and Wong Chun Sen from PSMTI.

According to Halim Lo, the board member of PSMTI Medan, candidates who run through PDIP were internally selected therefore they can guarantee the Chinese regarding the integrity of their candidate. "Allowing non-credible Chinese politicians in politic is political suicide for the Chinese. Their mistake will be a boomerang for the Chinese", Halim Lo emphasized the position of PSMTI and many Chinese leaders.

\section{Types of Patronage}

The 4 Chinese candidates of PSMTI prevent themselves from vote buying. They conducted programmatic politics by designing social programs in their electoral areas. Sofyan Tan conducted massive free health services program for the community. Long before the election, he provided social support for the community affected by flood and fire as well 
as a poor community through the economic program. Sofyan also often support religious and social-cultural activities. Therefore, the social bound between Sofyan and voters was quite strong. In addition, Sofyan has been largely published by local and national media for his social achievements. A book about him as a people-serving doctor, an educational figure with multiculturalism principle also contribute to his victory. Before the election, Sofyan also received an award from Maarif Institute for multiculturalism education and covered by the famous national magazine, Tempo as a high integrity political leader.

Brilian Moktar is the incumbent of North Sumatra DPRD uses development projects he initiated as an entry point to convince voters. While Hasyim and Wong Chun Sen also use social projects, health supports, and education to win the vote. They also managed to approach Non-Chinese community, mainly the Moslem and have huge support due to a social program, supports religious activities and attachment with Non-Chinese social-cultural leaders. Campaign issue is more focused on development, pluralism which relatively moderate and reaches into most of the electoral pools.

\section{CONCLUSION}

The successful Chinese candidates from Chinese social organizations have a relatively strong basis and network not only from the Chinese community but also from the NonChinese community. The social approach through concrete development projects, health, education and humanitarian support, fellowship received by the voters, fortified the clientelism network of PSMTI candidates who run through PDIP, compared to Chinese candidates from PASTI and INTI which less rooted.

Political identity is successfully formed through the leadership of candidates whose integrity have been selected by the community and supported by clan leaders and are financially supported and voted by the Chinese. This is the unique thing of Chinese politic. If non-Chinese candidates must cover the whole fund required - for the campaign, pay for winning structure and patronage distributed to the electoral, the PSMTI candidates are covered by the Chinese.

\section{REFERENCES}

(1) Allen Hicken, Clientalism, Annu. Rev. Polit. Sci. 2011. 14:289-310

(2) Benyamin K. Sovacool, "The political economy of oil and gas in Southeast Asia: heading towards the natural resource curse?", The Pacific Review, Vol. 23 No. 2 May 2010.

(3) Budi Agustono, Rekonstruksi Identitas Etnik, Sejarah Sosial Politik Orang Pakpak di Sumatera Utara 1958 2003, Disertasi Doktor, UGM, 2010
(4) Daniel J.Young, "Is Clientelism at Work in African Elections? a Study of Voting Behavior in Kenya and Zambia, Working Paper No. 106, 2009

(5) Edward Aspinall, "Money Politics: Patronage and Clientelism in Southeast Asia”, Draft paper 2013: For William Case (ed.) Handbook of Democracy in Southeast Asia (Routledge).

(6) Edward Aspinall dan Mada Sukmajati (ed), Politik Uang Di Indonesia, Patronase dan Klientelisme pada Pemilu Legislatif 2014, PolGov-UGM, 2016

(7) _ (ed), Electoral Dynamics in Indonesia, Money Politics, Patronage and Clientelism at the Grassroots, NUS Press Singapore, 2016

(8) Loren Ryter, Pemuda Pancasila: The Last Loyalist Free Men of Suharto New Order ? Indonesia, 66, Oktober, 1998

(9) _ Youth Gangs and Otherwise in Indonesia, paper for Global Gangs Workshop, Geneva, 2009

(10) John, T Sidel, "Bosisme dan Demokrasi di Filipina, Thailand, dan Indonesia", dalam John Harris, Kristian Stokke, dan Olle Tornquist (ed.). Politisasi Demokrasi: Politik Lokal Baru. Jakarta: Demos, 2005.

(11)Lucian W. Pye, "Money Politics and Transitions to Democracy in East Asia", Asian Survey, Vol. 37, No. 3 (Mar., 1997).

(12) Lucian N Leustean, Religious and Political Symbols in Post Modern Society, LSE, 2005

(13) Muriyanto Amin, "Kekuasaan dan Politik Lokal (Studi tentang Peran Pemuda Pancasila dalam Mendukung Syamsul Arifin dan Gatot Pudjonugroho sebagai Calon Gubernur dan Wakil Gubernur Provinsi Sumatera Utara Periode 2008-2013)", Disertasi Doktor UI, 2013

(14) Shinici Ichimura and Roy Bahl, Decentralization Policies in Asian Development, Georgia State University USA, 2008

(15) Susan Stokes, "What Killed Vote Buying in Britain?", a paper of a book project, Buying Votes: Distributive Politics in Democracies, co-authored with Thad Dunning of Yale University and Marcelo Nazareno and Valeria Brusco of the National University of Cordoba, Argentina, 2011

(16) Vedi R Hadiz, Indonesia A Decade After Reformasi: Continuity or Change ?, National University of Singapore, 2008

(17) Vincent P Vecora, Nations and Identities: Classic Readings, Blackwell Publisher, 2001

(18) Wolfgang Muno, "Conceptualizing and Measuring Clientelism", Paper to be presented at the workshop "Neopatrimonialism in Various World Regions" 23 August 2010, GIGA German Institute of Global and Area Studies, Hamburg. 